\title{
IMPROVE WATER PRODUCTIVITY OF WHEAT IN SHALLOW WATER TABLE AREA IN THE NORTH NILE DELTA, EGYPT
}

\author{
M.A. Mahmoud and A. Y. Elsadany \\ Soils, Water and Environment Research Institute, Agricultural Research Center, Giza, Egypt.
}

Received: Oct. 12,2017

Accepted: Nov. 2, 2017

\begin{abstract}
Two field experiments were established in 2014/2015 and 2015/2016 winter seasons at Sakha Agriculture Research Station (31 $07^{\prime} \mathrm{N}$ latitude, $30^{\circ} 05^{\prime} \mathrm{E}$ longitude), North Nile Delta, Egypt. Objective of the investigation is to improve productivity of water and wheat yield in shallow water table area. Irrigation scheduling treatments were assigned in the main plot, fertilizer levels were allocated in the sub-plots. While microorganisms treatments were allocated in sub sub-plots. Irrigation scheduling was done at $50 \% \pm 5\left(I_{1}\right)$, irrigation at $70 \% \pm 5\left(I_{2}\right)$ and irrigation at $90 \% \pm 5\left(I_{3}\right)$ of available soil moisture depletion (ASMD). Treatments of nitrogen fertilizer were $75 \%\left(F_{1}\right)$ and $100 \%\left(F_{2}\right)$ of the recommended nitrogen fertilizer. The plant growth promoting rhizobacteria treatments (PGPR) were cyanobacteria (Cy), Rhizobium $(R)$ and consortium cyanobacteria and Rhizobium $(C y+R)$ as well as the control treatment without inoculation (C).

Results revealed that there are no significant differences in grain yield, harvest index, number of spikes $m^{-2}$ and weight of 1000 grains between $I_{1}$ and $I_{2}$. Grain yield under $I_{3}$ decreased by $11 \%$ and $8 \%$ compared to $I_{1}$ and $I_{2}$ respectively over both growing seasons. The values of wheat consumptive use and irrigation water applied has the descending order $I_{1}>I_{2}>I_{3}$ over both growing seasons. The seasonal water consumptive use was $30.22,26.25$, and $22.81 \mathrm{~cm}$ for $I_{1}$, $I_{2}$ and $I_{3}$ respectively. Irrigation water applied was $39.02 \mathrm{~cm}$, distributed on five irrigations, 32.43 $\mathrm{cm}$, distributed on four irrigations, and $27.36 \mathrm{~cm}$ distributed on three irrigations including seedling irrigation for $I_{1}, I_{2}$ and $I_{3}$ respectively. Total seasonal water requirement was 50.0, 47.38 and $45.75 \mathrm{~cm}$ for $I_{1}, I_{2}$ and $I_{3}$ respectively over both seasons. Mean percentage of groundwater contribution has the descending order $I_{3}>I_{2}>I_{1}$ to be $46 \%, 26.9 \%$ and $10.2 \%$ for $I_{3}, I_{2}$ and $I_{1}$ respectively over both seasons.

So, when water becomes a limiting factor for wheat productivity in such area, farmers can apply $I_{3}$ with $F_{1}$ and $C y+R$ because it increased productivity of irrigation water (PIW) and water productivity (WP) by $37 \%$ and $79 \%$ respectively, as well as saved nitrogen fertilizer and irrigation water by $25 \%$ and $30 \%$ respectively compared to $I_{1}$ with $F_{2}$ and $C$.
\end{abstract}

Key words: Wheat, Scheduling irrigation, Groundwater contribution, Water productivity, Plant growth promoting rhizobacteria (PGPR)

\section{INTRODUCTION}

Wheat (Triticum aestivum L.) is one of the most important crops, worldwide it providing over $20 \%$ of the consumed calories by the world's population(Braun et al., 2010 and Safa and Samarasinghe, 2011). It is the most widely cultivated cereal globally with over $218 \mathrm{M}$ ha in cultivation (FAOSTAT, 2013). It is considered the important cereal crop in the world as well as in Egypt. It was grown on more that 1.38 million hectares from 2013- 2014
(Agricultural Economics Research Institute, 2015). So, one of the most important Egypt's aims is increasing wheat production to face the gap between production and the great demand of the highly increasing human population. Because of the projected limitation of water resources by climate change scenarios, worldwide requires serious attention to search for new water supplies for agriculture (Nouri et al., 2016). Also, water management in agricultural lands largely depends on quality and 
quantity of available water and soil resources (Jalali et al., 2017).

Scheduling irrigation and groundwater contribution in shallow water table areas such as North Nile Delta, Egypt are one of the important strategic practices to save irrigation water and increase productivity of irrigation water, moreover enhancing wheat yield. Irrigation water applied in surface irrigation may be reduced under shallow water table conditions (Kruse et al., 1986). The capillary contribution from a shallower groundwater table was generally higher than that from a deeper water table (Kang et al., 2002). Maintained water table at $1.5 \mathrm{~m}$ depth contributed to $25 \%$ of the total crop water use of safflower and irrigation applied without water table was $46 \%$ higher than water applied in the presence of water table(Soppe and Ayars, 2003). Wheat received its full water requirements from groundwater when, water table was maintained at $0.5 \mathrm{~m}$ depth (Kahlown et al., 2005). Many researchers reported that groundwater can contribute significantly to crop water needs under shallow water table, therefore it could be reduced applied irrigation and should consider this contribution when scheduling irrigation. This contribution may be range from 30 to $40 \%$ of total crop water use (Ayars et al., 2006), about $18 \%$ of the transpired water (Babajimopoulos et al., 2007), $40 \%$ of wheat water requirement from the groundwater (Gowing et al., 2009). The seasonally averaged ratio of the groundwater contribution to crop-water use reached as high as $75 \%$ in case of water table about $1.0 \mathrm{~m}$ depth and no irrigation (Luo and Sophocleous, 2010). At 1.5m groundwater table, the percentage of groundwater contribution to the ET attains 29\% (Huo et al., 2012). Capillary rise supplied $29 \%$ of the water use of wheat during ripening to harvest periods when the groundwater table was about $1.5 \mathrm{~m}$ depth (Karimov et al., 2014). Water productivity of the wheat biomass increases when groundwater levels decrease and increase groundwater contribution thus, the amount of irrigation water is reduced (Gowing et al., 2009; Huo et al., 2012; Karimov et al., 2014; Luo and Sophocleous, 2010; Sepaskhah et al., 2003; Soppe and Ayars, 2003 and Yang et al., 2007). So, The interval between irrigations can be increased when roots have been fully developed taking advantage of the presence of the groundwater (Babajimopoulos et al., 2007). and at the same time reducing the problem of disposing of drainage effluent(Gowing et al., 2009).

Besides water, nutrient is another key factor determining the growth and yield of crops (Li et al., 2009). Nitrogen (N) is a vital element in nutrition of plants and strongly influences crop yield. Improving nitrogenuse efficiency (NUE) is an important challenge to decline input cost to farmers, and harmful effect of $\mathrm{N}$ losses while maintaining crop yields. The interaction of complementary activities of water and $\mathrm{N}$ are the main factors that affect crop and resource productivity (water, N) the efficiency of crop production (Pandey et al., 2001 and Pradhan et al., 2014). Water productivity of wheat increased up to the application of $120 \mathrm{~kg} \mathrm{~N}^{-1}$ in all irrigation regimes(Pradhan et al., 2014). Plant growth promoting rhizobacteria (PGPR) can increase the ability of plants to tolerate the stress caused by drought and the same time can reduce the high nutrient requirements in crops production especially nitrogen fertilizer and costs of fertilization that disturb national economies and environmental soundness. Cyanobacterial inoculation as a source of nitrogen, organic matter, oxygen, solubilize phosphate, amino acids, vitamins, auxins, increase the fertilizer use efficiency and enhance plant growth of crop plants. $\mathrm{N}_{2}$ fixing cyanobacteria conservation of the supply of nutrients, providing a stable community that can diminish an attack by antagonists/stress factors and associated with roots of rice and wheat for improved plant growth and soil productivity (Prasanna et al., 2012). Synergistic effects of bacteria 
and cyanobacteria on wheat showed that the shoot weight, root weight, total biomass and panicle weight were higher compared to control (Nain et al., 2010). Inoculation by Rhizobuim and phosphate solubilizing bacteria significantly increased root and shoot weight, plant height, spike length, grain yield, grain content of phosphorus, leaf protein and leaf sugar content of the wheat plant (Afzal and Asghari, 2008). Rhizobial inoculation was increased the wheat yield component at both recommended and 20\% less of recommended doses NPK (Adnan et al., 2014). Rhizobium leguminosarum bv. trifolii was increased the shoot dry matter, grain yields and to avoid the deleterious effects of wheat (Hilali et al., 2001). Yanni et al., (2016) reported that, the inoculation by Rhizobium significantly increased wheat grain yield compared to the mean of farmers' yields using the same varieties in adjacent fields.
The main objective of this work is to improve on-farm water management in high water table areas through ground water contribution to water needs of wheat, increasing water productivity, and rationalization of irrigation water use, nitrogen fertilizer and plant growth promoting rhizobacteria (PGPR).

\section{MATERIALS AND METHODS Experimental site}

In winter seasons of 2014/2015 and 2015/2016, two field experiments were established at Sakha Agriculture Research Station (31 $31^{\circ} 07^{\prime} \mathrm{N}$ latitude, 30 $05^{\circ} \mathrm{E}$ longitude), Kafr El-Sheikh Governorate, North Nile Delta, Egypt. The Agrometeorological data were taken from Sakha Station during the growing winter seasons of $2014 / 2015$ and 2015/2016 as shown in Table (1).

Table (1): Monthly mean values of agro-meteorological data of Sakha Station in 2014 /2015 and 2015/2016 winter seasons.

\begin{tabular}{|c|c|c|c|c|c|c|c|c|c|c|}
\hline \multirow{2}{*}{ 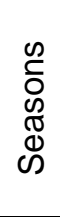 } & \multirow{2}{*}{ Months } & \multicolumn{3}{|c|}{ Air temperature } & \multicolumn{3}{|c|}{ Relative humidity } & \multirow{2}{*}{\begin{tabular}{|c|}
$\begin{array}{c}\text { Wind } \\
\text { speed }\end{array}$ \\
Mean \\
$\left(\mathrm{km} \mathrm{d}^{-1}\right)$
\end{tabular}} & \multirow{2}{*}{$\begin{array}{c}\text { Pan } \\
\text { evaporation } \\
\begin{array}{c}\text { Mean } \\
\left(\mathrm{mm} \mathrm{d}^{-1}\right)\end{array} \\
\end{array}$} & \multirow{2}{*}{$\begin{array}{c}\text { Rain } \\
\begin{array}{c}(\mathrm{mm} \\
\left.\text { month }^{-1}\right)\end{array}\end{array}$} \\
\hline & & $\begin{array}{l}\text { Max. } \\
\left({ }^{\circ} \mathrm{C}\right)\end{array}$ & $\begin{array}{l}\text { Min. } \\
\left({ }^{\circ} \mathrm{C}\right)\end{array}$ & $\begin{array}{c}\text { Mean } \\
\left({ }^{\circ} \mathrm{C}\right)\end{array}$ & $\begin{array}{c}\text { Max. } \\
(\%)\end{array}$ & $\begin{array}{l}\text { Min. } \\
(\%)\end{array}$ & $\begin{array}{c}\text { Mean } \\
(\%)\end{array}$ & & & \\
\hline \multirow{7}{*}{ 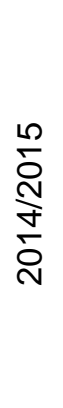 } & November & 24.30 & 13.79 & 19.05 & 87.80 & 60.50 & 74.15 & 67.30 & 2.77 & 24.60 \\
\hline & December & 22.27 & 9.72 & 16.00 & 88.60 & 63.50 & 76.05 & 46.03 & .72 & 5.70 \\
\hline & January & 18.79 & 6.46 & 12.61 & 88.10 & 61.10 & 74.60 & 70.80 & 2.71 & 52.55 \\
\hline & February & 19.01 & 7.69 & 13.35 & 86.80 & 62.70 & 74.75 & 72.91 & 2.90 & 38.80 \\
\hline & March & 22.69 & 11.69 & 17.19 & 82.36 & 58.82 & 70.59 & 87.64 & 3.23 & 6.25 \\
\hline & April & 25.64 & 13.70 & 19.67 & 78.30 & 48.50 & 63.40 & 95.70 & 6.07 & 23.90 \\
\hline & May & 30.19 & 18.79 & 24.49 & 77.30 & 46.10 & 61.70 & 114.60 & 7.15 & 00.00 \\
\hline \multirow{7}{*}{ 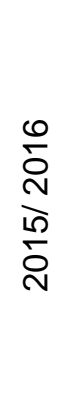 } & November & 24.40 & 14.42 & 19.41 & 87.00 & 64.20 & 75.60 & 70.30 & 3.19 & 52.40 \\
\hline & December & 19.70 & 8.36 & 14.03 & 88.60 & 67.20 & 77.90 & 57.20 & .50 & 25.00 \\
\hline & January & 18.40 & 6.35 & 12.38 & 85.60 & 62.50 & 74.05 & 69.20 & 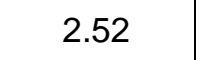 & 43.21 \\
\hline & February & 22.58 & 9.35 & 15.97 & 85.00 & 53.10 & 69.05 & 58.80 & 2.51 & 00.00 \\
\hline & March & 24.50 & 11.60 & 18.05 & 81.50 & 58.30 & 69.90 & 63.20 & 3.59 & 13.80 \\
\hline & April & 30.03 & 18.62 & 24.33 & 81.60 & 41.80 & 61.70 & 87.10 & 5.94 & 00.00 \\
\hline & May & 30.40 & 22.80 & 26.60 & 71.00 & 45.80 & 58.40 & 97.00 & 6.47 & 00.00 \\
\hline
\end{tabular}


Soil properties of the experiments site were determined before cultivation process, soil chemical properties were determined according to Page et al., (1982). Particlesize distribution was carried out using the pipette method according to Klute, (1986), soil field capacity, permanent wilting point were determined by using pressure membrane method at 0.33 and 15 Atm according to James, (1988). Soil bulk density was determined according to Vomocil, (1957) and total porosity P\% was computed using values of soil bulk density according to Black, (1965) as shown in Table (2).

\section{Experimental design and treatments:}

The experiment had designed as a split split-plot design with four replicates. The irrigation scheduling treatments were assigned in the main plot, fertilizer levels were allocated in the sub-plots, while the plant growth promoting rhizobacteria treatments (PGPR) were allocated in sub sub-plots. Irrigation scheduling treatments carried out at $50 \pm 5\left(\mathrm{I}_{1}\right), 70 \pm 5 \%\left(\mathrm{I}_{2}\right)$ and $90 \pm 5 \% \quad\left(I_{3}\right)$ of available soil moisture depletion (ASMD). Treatments of nitrogen fertilizer were $75 \%\left(F_{1}\right)$ and $100 \%\left(F_{2}\right)$ of the recommended nitrogen fertilizer. The PGPR treatments were: cyanobacteria (Cy), Rhizobium (R) and consortium cyanobacteria and Rhizobium (Cy+R) as well as the control treatment (C) without inoculation.

\section{Inoculant preparation:}

Peat as carrier was neutralized from its original $\mathrm{pH}$ of $5.0-5.5$ using $5 \%(\mathrm{w} / \mathrm{w})$ of $\mathrm{CaCO}_{3}$ and then pasteurized at $80{ }^{\circ} \mathrm{C}$ for 4 h. Rhizobium leguminosarum bv. trifolii was grown in yeast- extract mannitol (YEM ) liquid medium (Vincent, 1970) at $30{ }^{\circ} \mathrm{C}$ for three days with shaking and enumeration adjust of rhizobium populations in culture at $10^{6}-10^{7}$ colony - forming units (CFUs) $/ \mathrm{mL}$. Rhizobium culture was mixed with a sterilize peat carrier $(1 v / 2 w)$. Just before sowing, inoculation was mixed by wheat seeds slightly moistened by an adhesive component $(5 \%$ water solution of Arabic Gum). The proportion of the inoculum was equivalent to $720 \mathrm{~g}$ inoculum per $144 \mathrm{~kg}$ seeds (the seed quantity for cultivation of one hectare of field area). Anabaena oryzae and Anabaena cylindrica were grown in modified Watanabe medium (El- Nawawy et al., 1958) for 10 days under controlled laboratory conditions of $30 \pm 2{ }^{\circ} \mathrm{C}$ and continuous illumination of 5500-6500 Lux. Soil as the cyanobacteria carrier, $2.5 \mathrm{~cm}$ of soil is spread in try $(0.5 \times 1.0 \mathrm{~m})$ and covered with $5 \mathrm{~cm}$ tap water and supplied with phosphate $\left(0.2 \mathrm{~g} \mathrm{Na}_{2} \mathrm{HPO}_{4} / L\right)$, molybdenum $(0.2 \mathrm{mg} \mathrm{MoO} / \mathrm{L})$ and $1.0 \mathrm{~g}$ carbofuran. After the soil settles down and the water in the trays becomes clear, each tray was then inoculated with $100 \mathrm{ml}$ cyanobacteria culture of Anabaena oryzae and Anabaena cylindrica. The trays were kept in the open air up to 15 days and collected to dry. When completely dry, each dry cyanobacteria culture was thoroughly mixed together at the ratio of 1:1 (W/M) to represents the dried cyanobacteria inocula. Cyanobacteria inoculation was carried out 10 days after wheat sowing at the rate of $15 \mathrm{~kg}$ dried cyanobacteria crusts ha-1.

Wheat cv. Masr1 were sown in November $16^{\text {th }}, 2014$ in the first season and November $19^{\text {th }}, 2015$ in the second season, and harvested in May 1 ${ }^{\text {st }}, 2015$ and in May $3^{\text {rd }}$ 2016, respectively. Phosphate fertilizer was applied after plowing and before planting, as superphosphate $\left(15.5 \% \mathrm{P}_{2} \mathrm{O}_{5}\right)$ at the rate of $250 \mathrm{kgha}^{-1}$ and Potassium fertilizers was applied before planting at rate $115 \mathrm{~kg} \mathrm{ha}^{-1}$ in the form potassium sulfate $\left(48 \% \mathrm{~K}_{2} \mathrm{O}\right)$. The other agricultural practices were applied as the recommendations of Agricultural Research Center. 
Improve water productivity of wheat in shallow water table area in ..............

Table (2): Some soil physical and chemical properties of the experimental site as mean values of the two growth seasons.

\begin{tabular}{|c|c|c|c|c|c|c|c|c|c|c|}
\hline $\begin{array}{c}\text { Soil } \\
\text { depth } \\
(\mathrm{cm})\end{array}$ & $\begin{array}{c}\text { Field } \\
\text { capacity } \\
(\%)\end{array}$ & $\begin{array}{c}\text { Wilting } \\
\text { point } \\
(\%)\end{array}$ & $\begin{array}{c}\text { Bulk } \\
\text { density } \\
\left(\mathrm{Mg} \mathrm{m}^{-3}\right)\end{array}$ & $\begin{array}{c}\text { Total } \\
\text { porosity } \\
(\%)\end{array}$ & $\begin{array}{c}\text { Sand } \\
(\%)\end{array}$ & $\begin{array}{c}\text { Silt } \\
(\%)\end{array}$ & $\begin{array}{c}\text { Clay } \\
(\%)\end{array}$ & $\begin{array}{c}\text { Texture } \\
\text { class }\end{array}$ & $\begin{array}{c}\mathrm{EC}_{\mathrm{e}} \\
\left(\mathrm{dS} \mathrm{m}^{-1}\right)\end{array}$ & $\mathrm{pH}$ \\
\hline $0-15$ & 47.21 & 25.26 & 1.25 & 52.83 & 19.03 & 27.01 & 53.96 & Clayey & 2.08 & 8.18 \\
$15-30$ & 39.09 & 21.69 & 1.34 & 49.43 & 19.58 & 26.25 & 54.17 & Clayey & 2.34 & 8.29 \\
$30-45$ & 38.13 & 21.82 & 1.39 & 47.55 & 20.07 & 25.74 & 54.19 & Clayey & 2.61 & 8.37 \\
$45-60$ & 38.66 & 20.70 & 1.31 & 50.57 & 19.74 & 26.31 & 53.95 & Clayey & 2.93 & 8.52 \\
\hline Mean & 40.77 & 22.37 & 1.32 & 50.10 & 19.61 & 26.33 & 54.07 & Clay & 2.49 & 8.34 \\
\hline
\end{tabular}

\section{Irrigation Water Applied (IW)}

Soil moisture content was gravimetrically determined in soil samples which were taken from consecutive depths of $15 \mathrm{~cm}$ to $60 \mathrm{~cm}$. For irrigation timing, soil samples were taken periodically until it reaches the desired level of allowable moisture. The amount of water applied at each irrigation for each treatment was determined on the basis of raising the soil moisture content to its field capacity plus $10 \%$ as leaching requirements.

Irrigation water was pumped from the main canal near the experimental field into a settling basin with a baffle wall to maintain a constant head over the crest of a fixed rectangular weir. Irrigation water was calculated by using the equation as following:

Where,

$$
\mathrm{Q}=1.84 \mathrm{LH}^{1.5}
$$

$\mathrm{Q}=$ Rate of discharge, $\mathrm{m}^{3} / \mathrm{min}$., $\mathrm{L}=$ Length edge of weir, $\mathrm{cm}$

$\mathrm{H}=$ Height column of water above edge of weir, $\mathrm{cm}$

Irrigation water was controlled by a steel gate for each experiment plot as well as those fixed at the side of each feeder canal.

Seasonal applied water (AW), was calculated as described by Giriappa, (1983) as follows:

$A W=I W+E R+S$, where $I W=$ irrigation water applied, ER= effective rain and $S=$ amount of soil moisture contribution to consumptive use from the shallow ground water

Effective rainfall $=$ incident rainfall $\times 0.7$ (Novica, 1979).

\section{Water consumptive use (CU):}

Water consumptive use was determined as the soil moisture depletion (SMD) using the following equation (Israelsen and Hansen, 1962).

$$
\mathrm{CU}(\mathrm{SMD})=\sum_{i=1}^{n=4} \mathrm{Di} \times \mathrm{Bd} \times\left(\theta_{2}-\theta_{1}\right) / 100
$$

Where: $\mathrm{CU}=$ Water consumptive use $(\mathrm{cm}), \mathrm{D}=$ Soil depth layer $=15 \mathrm{~cm}, \mathrm{Bd}=$ Soil bulk density, $\left(\mathrm{Mg} \mathrm{m}^{-3}\right)$ for this depth, $\theta_{1}=$ Soil moisture $\%$ before irrigation, $\theta_{2}=$ Soil moisture \%, 48 hours after irrigation and $\mathrm{n}=$ Number of soil layers.

Crop evapotranspiration (ETc), was calculated using the following equation:

$\mathrm{ET}_{\mathrm{c}}=\mathrm{ET}_{\mathrm{o}} \times \mathrm{k}_{\mathrm{c}}$

Where, ETo refers to reference evapotranspiration and $\mathrm{Kc}$ refers to crop coefficient values which quoted from (Doorenbos et al., 1979). Reference evapotranspiration in the present study was calculated by two methods: Penman Montith (Allen et al., 1998) which calculated using FAO CROP WAT 8.0 software (Smith, 1992), and pan evaporation method using class A pan (Doorenbos and Pruitt, 1977). 


\section{Productivity of irrigation water (PIW) and water productivity (WP).}

The productivity of irrigation water (Ali et al., 2007) and water productivity (Paredes et al., 2017) of the grain yield as $\mathrm{kg} \mathrm{m}^{-3}$ were calculated as follow:

Productivity of irrigation water $\left(\mathrm{kg} \mathrm{m}^{-3}\right)=$

$\frac{\text { Grain yield } \mathrm{kg} \mathrm{ha}^{-1}}{\text { Irrigation water applied (IW) in } \mathrm{m}^{3} \mathrm{ha}^{-1}}$

Water productivity $\left(\mathrm{kg} \mathrm{m}^{-3}\right)=$

$$
\frac{\text { Grain yield } \mathrm{kg} \mathrm{ha}^{-1}}{\text { Total water applied (AW) in } \mathrm{m}^{3} \mathrm{ha}^{-1}}
$$

Where, AW includes rainfall, irrigation water applied and ground water contribution (Paredes et al., 2017).

\section{Fluctuation of groundwater table}

In order to establish the diagram of groundwater table fluctuation during the growing seasons, nine observation wells were installed along different treatment. Perforated plastic tube with each observation well was two inches in diameter and two meter long. Daily reading of groundwater table was recorded by the aid of metallic sounder that fixed in a sealed tape to measure the water table depth.

\section{Contribution of the groundwater table to crop water used (GWC \%)}

The contribution of groundwater table as a percentage of the consumptive use was calculated as follows:

$$
\mathrm{GWC} \%=(\mathrm{ETC}-\mathrm{SMD}) / \mathrm{ETC} \times 100
$$

Where ETc refers to Crop evapotranspiration and SMD refers to soil moisture depletion.

\section{The collected data}

Data collected were number of spikes $/ \mathrm{m}^{2}$, weight of 1000 grains weight, grain yield, straw yield and biomass yield at maturity. Data on number of tillers/ hill, weight of 1000 grain were taken on ten randomly selected guarded hills from the center of plots.

Harvest index $(\mathrm{HI})=$ Biomass yield in $\mathrm{kg}$ $\mathrm{ha}^{-1} /$ Grain yield in $\mathrm{kg} \mathrm{ha}^{-1}$

\section{The statistical analysis}

Statistical analysis of variance (ANOVA) was performed using MSTAT-C software. The data for the two years were combined. Treatment means were compared using Duncan's multiple range test which was statistically significant when $P \leq 0.05$ according (Duncan, 1955).

\section{RESULTS AND DISCUSSION Wheat yield and yield components}

Data in Table (3) show that there were no significant differences in grain yield, harvest index number of spikes $\mathrm{m}^{-2}$ and weight of 1000 grains between irrigation treatments $I_{1}$ and $I_{2}$, however there are significant differences on straw yield and biomass yield between irrigation treatments $I_{1}$ and $I_{2}$ over both growing seasons. In compression with irrigation treatments of $I_{1}$ and $I_{2}$, irrigation treatment of $I_{3}$ gave less values in yields of grain, straw, biomass, harvest index, number of spikes $\mathrm{m}^{-2}$ and weight of 1000 grains. Grain yield resulted from irrigation treatment of $I_{3}$ decreased by $11 \%$ and $8 \%$ compared with $I_{1}$ and $I_{2}$ respectively over both growing seasons due to lower yield component such as number of spikes and 1000-grain weight (Table 3). These decrease in yield and its attributes may be due to negative impact of lower water supply (Hammad and Ali, 2014; Namich, 2007 and Osborne et al., 2002). Water deficit could limit leaf expansion and elongation through inhibiting cell expansion (Namich, 2007). Also, drought reduce turgor pressure in cell, thus inhibiting enlargement and cell splitting causing slow plant growth and reduction of dry mass accumulation (Delfine et al., 2002).

It is obvious from the same table that the highest values of grain yield, straw yield, biomass yield, harvest index, number of 
spikes $\mathrm{m}^{-2}$ and weight of 1000 grains were obtained with $F_{2}$ compared to $F_{1}$ and these parameters gave the highest values with the inoculation by the consortium (cyanobacteria and Rhizobium) compared to cyanobacteria, Rhizobium both alone and control. This is a results of the synergistic effects of the nitrogen fixing cyanobacteria which a source of nitrogen, organic matter, oxygen to the rhizosphere, solubilize phosphate, amino acids, vitamins, auxins, increase the fertilizer use efficiency and enhance plant growth of crop plants (Prasanna et al., 2012). And
Rhizobium capability to survive and improving seedling growth under drought of wheat (Hussain et al., 2014). The interaction between irrigation $\times$ PGPR, nitrogen levels $\times$ PGPR and irrigation $x$ nitrogen levels $x$ PGPR had a highly significant effect on wheat yield and its attributes, while no significant differences of grain yield, straw yield, biomass yield, harvest index, number of spikes $\mathrm{m}^{-2}$ and weight of 1000 grains for irrigation $\times$ nitrogen levels $\times$ PGPR $\times$ years interaction.

Table (3): Mean values of wheat yield and yield component as influenced by irrigation treatments, nitrogen levels and PGPR treatments in combined analysis of 2014/ 2015 and 2015/2016 seasons.

\begin{tabular}{|c|c|c|c|c|c|c|}
\hline Treatments & $\begin{array}{l}\text { Grain } \\
\text { yield } \\
\left(\mathrm{t} \mathrm{ha}^{-1}\right)\end{array}$ & $\begin{array}{c}\text { Straw } \\
\text { yield } \\
\left(\mathrm{t} \mathrm{ha}^{-1}\right)\end{array}$ & $\begin{array}{c}\text { Biomass } \\
\text { yield } \\
\left(\mathrm{t} \mathrm{ha}^{-1}\right) \\
\end{array}$ & $\begin{array}{c}\text { Harvest } \\
\text { index }\end{array}$ & $\begin{array}{c}\text { No. of } \\
\text { spikes } \mathrm{m}^{-2}\end{array}$ & $\begin{array}{c}\text { Weight of } \\
1000 \\
\text { grains }(\mathrm{g})\end{array}$ \\
\hline \multicolumn{7}{|l|}{ Irrigation } \\
\hline $\mathrm{I}_{1}$ & $8.075^{a}$ & $10.770^{\mathrm{a}}$ & $18.844^{\mathrm{a}}$ & $0.43^{\mathrm{a}}$ & $589^{a}$ & $37.58^{a}$ \\
\hline $\mathrm{I}_{2}$ & $7.817^{a}$ & $10.189^{b}$ & $18.006^{b}$ & $0.43^{a}$ & $559^{a b}$ & $36.84^{a}$ \\
\hline $\mathrm{I}_{3}$ & $7.187^{b}$ & $10.235^{b}$ & $17.423^{c}$ & $0.41^{b}$ & $529^{b}$ & $35.78^{b}$ \\
\hline \multicolumn{7}{|l|}{ Fertilizer } \\
\hline$F_{1}$ & $7.272^{b}$ & $10.012^{b}$ & $17.284^{b}$ & $0.42^{a}$ & $547^{b}$ & $35.71^{b}$ \\
\hline $\mathrm{F}_{2}$ & $8.114^{a}$ & $10.783^{a}$ & $18.898^{a}$ & $0.43^{\mathrm{a}}$ & $571^{a}$ & $37.75^{a}$ \\
\hline \multicolumn{7}{|l|}{ PGPR } \\
\hline C & $6.173^{c}$ & $10.050^{b}$ & $16.223^{c}$ & $0.39^{c}$ & $464^{d}$ & $32.60^{b}$ \\
\hline $\mathrm{R}$ & $7.643^{b}$ & $10.640 a$ & $18.283^{b}$ & $0.42^{b}$ & $563^{c}$ & $38.11^{\mathrm{a}}$ \\
\hline Cy & $8.045^{b}$ & $10.259^{a b}$ & $18.304^{b}$ & $0.44^{\mathrm{ab}}$ & $581^{b}$ & $37.74^{a}$ \\
\hline Cy $+R$ & $8.911^{a}$ & $10.642^{\mathrm{a}}$ & $19.553^{a}$ & $0.46^{a}$ & $629^{a}$ & $38.47^{a}$ \\
\hline $\mathrm{I} \times \mathrm{F}$ & ** & ** & ** & ** & ** & ns \\
\hline I $\times$ PGPR & ** & ** & ** & ** & ** & ** \\
\hline$F \times P G P R$ & * & ** & ** & ** & * & ** \\
\hline$I \times F \times P G P R$ & ** & ** & ** & ** & ** & ** \\
\hline $\mathrm{I} \times \mathrm{F} \times \mathrm{PGPR} \times$ year & ns & ns & ns & ns & ns & ns \\
\hline
\end{tabular}

Means designed by the same letter at each cell are not significantly different at the $5 \%$ Level according to Duncan's multiple range test n.s: Indicate not significant. 
The highest values of grain yield, straw yield, biomass yield and number of spikes $\mathrm{m}^{-2}$ and weight of 1000 grains were obtained under $I_{1} \times F_{2}$ interaction, while the lowest values of grain yield, harvest index, number of spikes $\mathrm{m}^{-2}$ and weight of 1000 grains were obtained under $I_{3} \times F_{1}$ interaction. The lowest values of straw yield and biomass yield were obtained under $I_{1} \times F_{1}$ interaction over both growing seasons, this may be due to the nutrients uptake increase with decreasing the soil moisture depletion (Nwachukwu and Ikeadigh, 2012 and Rizk and Sherif, 2014) as shown in Table (4). The interaction between scheduling irrigation and plant growth promoting rhizobacteria had a significant effect on wheat yield and its components. As shown in Table 4, the highest values of weight of 1000 grains, straw yield $\left(\mathrm{t} \mathrm{ha}{ }^{-1}\right)$, biomass yield $\left(\mathrm{t} \mathrm{ha} \mathrm{a}^{-1}\right)$ and No. of spikes $\mathrm{m}^{-2}$ resulted from irrigation at $I_{1}$ with $C y+R$, while the highest values of grain yield and harvest index were obtained under $\mathrm{I}_{2}$ with $\mathrm{C} y+\mathrm{R}$ in over both growing seasons. PGPR induced physical and chemical changes in plants that resulted in enhancement tolerance to abiotic stress. It had proved its significance in plant growth promotion through enhanced nutrient acquisition, phytohormone production, and biological control (Nakkeeran et al., 2005). More recent studies reported that the effects of PGPR on different plants through their increase the ability to tolerate the several abiotic stress factors, including drought (Dimkpa et al., 2009 and Yang et al., 2009). Wheat plants inoculated by PGPR are able to feel drier soil more quickly and produce non- hydraulic root-sourced signals earlier, total leaf areas larger, photosynthetic products accumulated, higher shoot dry weight and water use efficiency than noninoculated under water stress condition(Zhu et al., 2014).

The lowest values of wheat yield and its attributes were obtained under $I_{3} \times C$. In general application of a consortium of cyanobacteria and Rhizobium give positive effects in yield and its attributes with different irrigation treatments in both two growing seasons.

The interaction between fertilizer levels and PGPR treatments showed that the highest values of grain yield, biomass yield, harvest index, number of spikes $\mathrm{m}^{-2}$ and weight of 1000 grains were obtained under $F_{2} \times C y+R$ interaction, while the lowest values of the same wheat yield and its attributes resulted from $F_{1} \times C$ interaction over both growing seasons as shown in Table (5). Mussa et al., (2003) found that, the wheat plants inoculation with cyanobacteria enhanced the nitrogen use efficiency.

The highest values of grain yield, number of spikes $\mathrm{m}^{-2}$ and weight of 1000 grains were obtained under $\mathrm{I}_{1} \times \mathrm{F}_{2} \times \mathrm{C}+\mathrm{R}$ and $\mathrm{I}_{2} \times \mathrm{F}_{2} \times$ $\mathrm{Cy}+\mathrm{R}$ without any significant differences between them over both two growing seasons. Whereas the highest values of the harvest index were obtained under $I_{2} \times F_{2} \times$ $\mathrm{C} y+\mathrm{R}$ interaction over the both growing seasons. However, the lowest values of grain yield, harvest index and weight of 1000 grain resulted from $\mathrm{I}_{3} \times \mathrm{F}_{1} \times \mathrm{C}$ interaction over both two growing seasons. The highest values of straw yield, biomass yield and number of spikes $\mathrm{m}^{-2}$ were obtained under $\mathrm{I}_{1}$ $\times \mathrm{F}_{2} \times \mathrm{Cy}+\mathrm{R}$ interaction, while the lowest values of straw yield and biomass yield resulted from $I_{1} \times F_{1} \times C$ interaction over both growing seasons as shown in Table (6). Cyanobacteria are the best models for planning strategies to manage agricultural water stress in an eco-friendly manner, and use of $\mathrm{N}_{2}$ - cyanobacteria as biofertilizer or a plant growth regulator consider improver in arid soils (Apte, 2001).

The highest values of grain yield resulted from $I_{1} \times F_{2} \times$ Cy to be $10.357 \mathrm{t} \mathrm{ha}^{-1}$ followed by $I_{1} \times F_{2} \times C y+R$ which produced $9.818 \mathrm{t} \mathrm{ha}^{-1}$ and $\mathrm{I}_{2} \times \mathrm{F}_{1} \times \mathrm{Cy}+\mathrm{R}$ which produced $9.249 \mathrm{t} \mathrm{ha}^{-1}$ and $\mathrm{I}_{3} \times \mathrm{F}_{1} \times \mathrm{Cy}+\mathrm{R}$ which produced $8.820 \mathrm{t} \mathrm{ha}^{-1}$. Keeping on the economic productivity under water shortage 
requires applying $I_{2} \times F_{1} \times C y+R$ or $I_{3} \times F_{1}$ $\times$ Cy+R. This depends mainly on the level of water shortage required for the economic yield. In other words, under the conditions of irrigation water shortage for wheat productivity, farmer should apply $I_{2} \times F_{1} \times$ Cy+R which produced $9.249 \mathrm{t} \mathrm{ha}^{-1}$ or $\mathrm{I}_{3} \times$ $\mathrm{F}_{1} \times \mathrm{Cy}+\mathrm{R}$ which produced $8.820 \mathrm{tha}^{-1}$.

Table (4): The interaction between irrigation treatments $\times$ fertilizer levels and irrigation treatments $\times$ PGPR on wheat yield and its components in combined analysis over both growing seasons.

\begin{tabular}{|c|c|c|c|c|c|c|}
\hline \multirow[t]{2}{*}{ Irrigation } & \multicolumn{2}{|c|}{ Fertilizer } & \multicolumn{4}{|c|}{ PGPR } \\
\hline & $\mathrm{F}_{1}$ & $\mathrm{~F}_{2}$ & $\mathrm{C}$ & $\mathrm{R}$ & Cy & Cy+R \\
\hline \multicolumn{7}{|c|}{ Grain yield (t ha-1) } \\
\hline $\mathrm{I}_{1}$ & $7.307^{d}$ & $8.842^{\mathrm{a}}$ & $6.607^{g}$ & $8.032^{\mathrm{de}}$ & $9.229^{a b}$ & $8.431^{\mathrm{bcd}}$ \\
\hline $\mathrm{I}_{2}$ & $7.717^{\mathrm{bc}}$ & $7.918^{\mathrm{b}}$ & $6.298^{g h}$ & $8.087^{\text {cde }}$ & $7.478^{\mathrm{ef}}$ & $9.407^{a}$ \\
\hline$I_{3}$ & $6.792^{\mathrm{e}}$ & $7.583^{\mathrm{cd}}$ & $5.615^{\mathrm{h}}$ & $6.811^{\mathrm{fg}}$ & $7.429^{\mathrm{ef}}$ & $8.896^{a b c}$ \\
\hline \multicolumn{7}{|c|}{ Straw yield $\left(\mathrm{t} \mathrm{ha}^{-1}\right)$} \\
\hline $\mathrm{I}_{1}$ & $8.865^{d}$ & $12.674^{a}$ & $9.673^{d}$ & $10.604^{\mathrm{bc}}$ & $10.706^{\mathrm{bc}}$ & $12.097^{a}$ \\
\hline $\mathrm{I}_{2}$ & $10.641^{b}$ & $9.736 c$ & $9.934^{\mathrm{cd}}$ & $10.299^{\mathrm{bcd}}$ & $10.401^{\mathrm{bcd}}$ & $10.121^{\mathrm{cd}}$ \\
\hline $\mathrm{I}_{3}$ & $10.530^{\mathrm{b}}$ & $9.941^{b c}$ & $10.544^{\mathrm{bc}}$ & $11.017^{\mathrm{b}}$ & $9.669^{d}$ & $9.711^{d}$ \\
\hline \multicolumn{7}{|c|}{ Biomass yield $\left(\mathrm{t} \mathrm{ha}^{-1}\right)$} \\
\hline $\mathrm{I}_{1}$ & $16.172^{d}$ & $21.517^{a}$ & $16.279^{f}$ & $18.636^{c}$ & $19.935^{\mathrm{ab}}$ & $20.528^{a}$ \\
\hline $\mathrm{I}_{2}$ & $18.358^{b}$ & $17.654^{c}$ & $16.232^{f}$ & $18.386^{\mathrm{cd}}$ & $17.879^{\text {cde }}$ & $19.528^{b}$ \\
\hline $\mathrm{I}_{3}$ & $17.322^{c}$ & $17.524^{c}$ & $16.158^{f}$ & $17.829^{\text {de }}$ & $17.098^{\mathrm{e}}$ & $18.607^{\mathrm{cd}}$ \\
\hline \multicolumn{7}{|c|}{ Harvest index } \\
\hline $\mathrm{I}_{1}$ & $0.45^{a b}$ & $0.41^{\mathrm{de}}$ & $0.42^{\text {de }}$ & $0.44^{\mathrm{bcd}}$ & $0.46^{\mathrm{abc}}$ & $0.41^{\text {de }}$ \\
\hline $\mathrm{I}_{2}$ & $0.42^{\mathrm{cd}}$ & $0.45^{\mathrm{ab}}$ & $0.39^{\text {ef }}$ & $0.44^{\mathrm{bcd}}$ & $0.41^{\text {de }}$ & $0.48^{\mathrm{ab}}$ \\
\hline $\mathrm{I}_{3}$ & $0.39^{e}$ & $0.43^{b c}$ & $0.35^{f}$ & $0.38^{\text {ef }}$ & $0.44^{\mathrm{bcd}}$ & $0.48^{\mathrm{ab}}$ \\
\hline \multicolumn{7}{|c|}{ No. of Spikes $\mathrm{m}^{-2}$} \\
\hline $\mathrm{I}_{1}$ & $559^{b c}$ & $619^{a}$ & $513^{e}$ & $579^{c}$ & $608^{b}$ & $657^{a}$ \\
\hline $\mathrm{I}_{2}$ & $548^{\mathrm{bc}}$ & $548^{\mathrm{bc}}$ & $440^{f}$ & $569^{c}$ & $571^{c}$ & $656^{a}$ \\
\hline$I_{3}$ & $513^{d}$ & $546^{c}$ & $438^{f}$ & $542^{d}$ & $564^{\mathrm{cd}}$ & $573^{c}$ \\
\hline \multicolumn{7}{|c|}{ Weight of 1000 grains } \\
\hline $\mathrm{I}_{1}$ & $36.88^{a}$ & $38.27^{a}$ & $31.10^{\mathrm{g}}$ & $40.32^{a b}$ & $37.35^{\text {cde }}$ & $41.55^{a}$ \\
\hline $\mathrm{I}_{2}$ & $36.97^{a}$ & $36.72^{\mathrm{a}}$ & $34.45^{f}$ & $38.53^{\mathrm{bcd}}$ & $38.94^{b c}$ & $35.47^{\text {ef }}$ \\
\hline $\mathrm{I}_{3}$ & $33.30^{\mathrm{b}}$ & $38.26^{a}$ & $32.25^{\mathrm{g}}$ & $35.50^{\text {ef }}$ & $36.94^{\text {de }}$ & $38.42^{\mathrm{bcd}}$ \\
\hline
\end{tabular}

Means designed by the same letter at each cell are not significantly different at the $5 \%$ Level according to Duncan's multiple range test 
Table (5): The interaction between plant growth promoting rhizobacteria (PGPR) and fertilizer on wheat yield and its components in combined analysis of 1 st and $2^{\text {nd }}$ seasons.

\begin{tabular}{|c|c|c|c|c|c|c|}
\hline \multirow{2}{*}{ PGPR } & \multicolumn{2}{|c|}{ Fertilizer } & \multicolumn{2}{|c|}{ Fertilizer } & \multicolumn{2}{|c|}{ Fertilizer } \\
\hline & $\mathrm{F}_{1}$ & $\mathrm{~F}_{2}$ & $\mathrm{~F}_{1}$ & $\mathrm{~F}_{2}$ & $\mathrm{~F}_{1}$ & $\mathrm{~F}_{2}$ \\
\hline & \multicolumn{2}{|c|}{ Grain yield ( $\left.\mathrm{t} \mathrm{ha}{ }^{-1}\right)$} & \multicolumn{2}{|c|}{ Straw yield $\left(\mathrm{t} \mathrm{ha}{ }^{-1}\right)$} & \multicolumn{2}{|c|}{ Biomass yield $\left(\mathrm{t} \mathrm{ha}^{-1}\right)$} \\
\hline C & $5.625^{e}$ & $6.721^{d}$ & $10.137^{\mathrm{bcd}}$ & $9.963^{\text {cde }}$ & $15.762^{\mathrm{e}}$ & $16.684^{d}$ \\
\hline $\mathrm{R}$ & $7.645^{c}$ & $7.641^{\mathrm{c}}$ & $9.333^{\mathrm{e}}$ & $11.946^{\mathrm{a}}$ & $16.979^{\mathrm{cd}}$ & $19.587^{a b}$ \\
\hline Cy & $7.446^{c}$ & $8.645^{b}$ & $9.886^{\mathrm{de}}$ & $10.632^{\mathrm{bc}}$ & $17.331^{\mathrm{c}}$ & $19.277^{b}$ \\
\hline \multirow[t]{2}{*}{$\mathrm{Cy}+\mathrm{R}$} & $8.371^{b}$ & $9.452^{\mathrm{a}}$ & $10.693^{b}$ & $10.593^{b c}$ & $19.064^{\mathrm{b}}$ & $20.044^{\mathrm{a}}$ \\
\hline & \multicolumn{2}{|c|}{ Harvest index } & \multicolumn{2}{|c|}{ No. of Spikes $\mathrm{m}^{-2}$} & \multicolumn{2}{|c|}{ Weight of 1000 grains $(\mathrm{g})$} \\
\hline C & $0.37^{e}$ & $0.41^{\mathrm{cd}}$ & $445^{f}$ & $483^{e}$ & $31.74^{\mathrm{e}}$ & $33.46^{d}$ \\
\hline $\mathrm{R}$ & $0.45^{a b}$ & $0.39^{\text {de }}$ & $549^{d}$ & $578^{c}$ & $38.01^{b}$ & $38.23^{b}$ \\
\hline Сy & $0.43^{b c}$ & $0.45^{\mathrm{ab}}$ & $581^{\mathrm{c}}$ & $581^{c}$ & $37.16^{\mathrm{bc}}$ & $38.32^{b}$ \\
\hline$C y+R$ & $0.44^{\mathrm{bc}}$ & $0.47^{\mathrm{a}}$ & $616^{b}$ & $641^{a}$ & $35.95^{c}$ & $41.02^{\mathrm{a}}$ \\
\hline
\end{tabular}

Means designed by the same letter at each cell are not significantly different at the $5 \%$ Level according to Duncan's multiple range test.

\section{Wheat water consumptive use and applied irrigation water}

Data in Table (7) indicate that, the peak values of wheat water consumptive use were in March during the flowering stage. There are visible differences of the values of wheat water consumptive use between irrigation treatments and fertilizer levels. A slight increase was observed in water consumptive use in favour of treatment of $F_{2}$ compared to $F_{1}$ treatment. This increment may be attributed to nitrogen fertilizer which increased photosynthetic activity and promote the growth of the plants (Pradhan et al., 2014), but there are no obvious differences in the values of water consumptive use between PGPR treatments as a mean of the two growing seasons. Also, there are no clear differences in the values of irrigation water applied between nitrogen levels and PGPR treatments.

The values of wheat consumptive use and irrigation water applied has the descending order $I_{1}>I_{2}>I_{3}$ over both growing seasons, this may be due to increase the number of irrigations during growing season (Eldardiry et al., 2010 and Khan et al., 2007), obtained results agree with data presented by (FAO, 2010 and Rizk and Sherif, 2014), they concluded that total cumulative evapotranspiration increased with more applied irrigation and increasing available soil moisture compared with less irrigation. The amount of irrigation water applied over both growing seasons was $39.02,32.43$ and $27.36 \mathrm{~cm}$ for irrigated wheat plants at $50 \% \pm 5\left(\mathrm{I}_{1}\right)$, irrigation at $70 \%$ $\pm 5\left(\mathrm{I}_{2}\right)$ and irrigation at $90 \% \pm 5$ of ASMD respectively. Amount of irrigation water at $50 \% \pm 5$ of ASMD was the highest and distributed on five irrigations involving the seeding irrigation while amount of irrigation at $90 \% \pm 5$ of $A S M D$ was the least value, and distributed on three irrigations including seeding irrigation. Amount of irrigation water at $70 \% \pm 5$ ASMD was between $50 \% \pm 5$ and $90 \% \pm 5$ of $A S M D$ and distributed on four irrigations having seeding irrigation. Also, irrigation water applied decreased by $17 \%$ and $30 \%$ under $I_{2}$ and $I_{3}$ respectively compared to $I_{1}$ as a mean of the two growing seasons, this may be due to deficit irrigation which reduce irrigation water application(Karrou et al., 2012) as shown in Table (7). 
Table (6): Effect of the interaction among irrigation treatments, nitrogen levels and PGPR on wheat yield and its components over both seasons.

\begin{tabular}{|c|c|c|c|c|c|c|c|c|}
\hline \multicolumn{3}{|c|}{ Treatments } & \multicolumn{6}{|c|}{ Parameters } \\
\hline & & & $\begin{array}{c}\text { Grain yield } \\
\left(\mathrm{t} \mathrm{ha}^{-1}\right)\end{array}$ & $\begin{array}{c}\text { Straw yield } \\
\left(\mathrm{t} \mathrm{ha}^{-1}\right)\end{array}$ & $\begin{array}{c}\text { Biomass } \\
\text { yield } \\
\left(\mathrm{t} \mathrm{ha}^{-1}\right)\end{array}$ & $\begin{array}{l}\text { Harvest } \\
\text { index }\end{array}$ & $\begin{array}{c}\text { No. of } \\
\text { Spikes } \mathrm{m}^{-2}\end{array}$ & $\begin{array}{l}\text { Weight } \\
\text { of } 1000 \\
\text { grains } \\
\text { (g) }\end{array}$ \\
\hline \multirow{8}{*}{$I_{1}$} & & C & $6.182^{\mathrm{ij}}$ & $7.098^{1}$ & $13.280^{k}$ & $0.47^{\mathrm{abcde}}$ & $490^{\mathrm{kl}}$ & $30.42^{\mathrm{hi}}$ \\
\hline & & $\mathrm{R}$ & $7.900^{\text {defg }}$ & $7.808^{\mathrm{kl}}$ & $15.708^{\mathrm{ij}}$ & $0.50^{\mathrm{ab}}$ & $540^{\text {hij }}$ & $40.32^{\mathrm{ab}}$ \\
\hline & & Cy & $8.102^{\text {cdef }}$ & $9.391^{\text {hij }}$ & $17.493^{g h}$ & 0.46 bcde & $570^{\text {fgh }}$ & $35.55^{\text {def }}$ \\
\hline & & $\mathrm{Cy}+\mathrm{R}$ & $7.044^{\text {fghij }}$ & $11.163^{\text {defg }}$ & $18.207^{\text {defg }}$ & $0.39^{\text {hij }}$ & $637^{\mathrm{bc}}$ & $41.24^{a}$ \\
\hline & & $C$ & $7.031^{\text {fghij }}$ & $12.247^{\mathrm{abcd}}$ & $19.278^{d}$ & $0.36^{i j}$ & $536^{\mathrm{ij}}$ & $31.77 \mathrm{ghi}$ \\
\hline & & $\mathrm{R}$ & $8.163^{\text {cdef }}$ & $13.399^{a}$ & $21.563^{b c}$ & $0.38^{\mathrm{hij}}$ & $617^{\mathrm{cd}}$ & $40.32^{\mathrm{ab}}$ \\
\hline & & Cy & $10.357^{a}$ & $12.020^{\text {bcde }}$ & $22.377^{\mathrm{ab}}$ & $0.46^{\text {bcde }}$ & $645^{a b c}$ & $39.15^{a b c}$ \\
\hline & & $C y+R$ & $9.818^{\mathrm{ab}}$ & $13.030 \mathrm{ab}$ & $22.848^{a}$ & $0.43^{\text {defgh }}$ & $676^{a}$ & $41.86^{a}$ \\
\hline \multirow{8}{*}{$\mathrm{I}_{2}$} & & C & $5.861^{\mathrm{jk}}$ & $10.609^{f g}$ & $16.470^{\mathrm{hi}}$ & $0.36^{\mathrm{j}}$ & $420^{\circ}$ & $35.63^{\mathrm{def}}$ \\
\hline & & $\mathrm{R}$ & $8.808^{\text {bcde }}$ & $9.042^{\mathrm{ij}}$ & $17.850^{\mathrm{fg}}$ & $0.49^{a b c}$ & $594^{\text {def }}$ & $40.71^{\mathrm{ab}}$ \\
\hline & & Cy & $6.948^{\text {fghij }}$ & $11.387^{\text {def }}$ & $18.336^{\text {defg }}$ & $0.38^{\mathrm{hij}}$ & $602^{\mathrm{de}}$ & $41.27^{a}$ \\
\hline & & $\mathrm{Cy}+\mathrm{R}$ & $9.249^{a b c}$ & $11.528^{\mathrm{def}}$ & $20.777^{c}$ & $0.45^{\text {bcdefg }}$ & $666^{\mathrm{ab}}$ & $30.27^{\mathrm{hi}}$ \\
\hline & & C & $6.734^{\text {ghij }}$ & $9.259^{\mathrm{ij}}$ & $15.994^{i}$ & $0.42^{\text {efghi }}$ & $460^{l m}$ & $33.28^{\mathrm{fg}}$ \\
\hline & & $\mathrm{R}$ & $7.365^{\text {fghi }}$ & $11.556^{\text {cdef }}$ & $18.921^{\text {def }}$ & $0.39^{\text {ghij }}$ & $544^{\text {ghi }}$ & $36.34^{\mathrm{de}}$ \\
\hline & 12 & Cy & $8.007^{\text {cdefg }}$ & $9.414^{\mathrm{hij}}$ & $17.422^{g h}$ & $0.45^{\text {bcdef }}$ & $540^{\text {hij }}$ & $36.60^{\text {cde }}$ \\
\hline & & $\mathrm{Cy}+\mathrm{R}$ & $9.565^{\mathrm{ab}}$ & $8.713^{\mathrm{jk}}$ & $18.278^{\text {defg }}$ & $0.52^{\mathrm{a}}$ & $646^{a b c}$ & $40.66^{a b}$ \\
\hline \multirow{8}{*}{$I_{3}$} & & C & $4.832^{k}$ & $12.704^{\mathrm{abc}}$ & $17.536^{\mathrm{gh}}$ & $0.27 \mathrm{k}$ & $424^{\text {no }}$ & $29.17^{i}$ \\
\hline & & $\mathrm{R}$ & $6.228^{i j}$ & $11.150^{\text {defg }}$ & $17.379 \mathrm{gh}$ & $0.36^{j}$ & $512^{\mathrm{jk}}$ & $33.00^{\text {fgh }}$ \\
\hline & $\Gamma 1$ & Cy & $7.287^{\mathrm{fghi}}$ & $8.878^{\mathrm{jk}}$ & $16.165^{i}$ & $0.45^{\text {bcdef }}$ & $570^{\text {fgh }}$ & $34.67^{\mathrm{ef}}$ \\
\hline & & $C y+R$ & $8.820^{\text {bcde }}$ & $9.387^{\text {hij }}$ & $18.207^{\text {defg }}$ & $0.48^{a b c d}$ & $544^{\text {ghi }}$ & $36.33^{\text {de }}$ \\
\hline & \multirow{4}{*}{$F_{2}$} & C & $6.397^{\mathrm{hij}}$ & $8.383^{\mathrm{jk}}$ & $14.780^{\mathrm{j}}$ & $0.43^{\text {cdefgh }}$ & $452^{m n}$ & $35.33^{\mathrm{def}}$ \\
\hline & & $\mathrm{R}$ & $7.394^{\text {fghi }}$ & $10.884^{\text {efg }}$ & $18.278^{\text {defg }}$ & $0.40^{\text {fghij }}$ & $572^{\text {efg }}$ & $38.00^{\mathrm{bcd}}$ \\
\hline & & Cy & $7.570^{\text {efgh }}$ & $10.460^{\mathrm{fgh}}$ & $18.031^{\mathrm{efg}}$ & $0.42^{\text {efghi }}$ & $558^{\text {ghi }}$ & $39.21^{\mathrm{abc}}$ \\
\hline & & $\mathrm{Cy}+\mathrm{R}$ & $8.972^{\mathrm{bcd}}$ & $10.035^{\mathrm{ghi}}$ & $19.007^{\mathrm{de}}$ & $0.47^{\text {abcde }}$ & $602^{\text {de }}$ & $40.49^{a b}$ \\
\hline
\end{tabular}

Means designed by the same letter at each cell are not significantly different at the $5 \%$ Level according to Duncan's multiple range test 
M.A. Mahmoud and A. Y. Elsadany

Table (7): Monthly, seasonal water consumptive use (CU) and seasonal irrigation water applied (IW) of wheat as a means of the two growing seasons

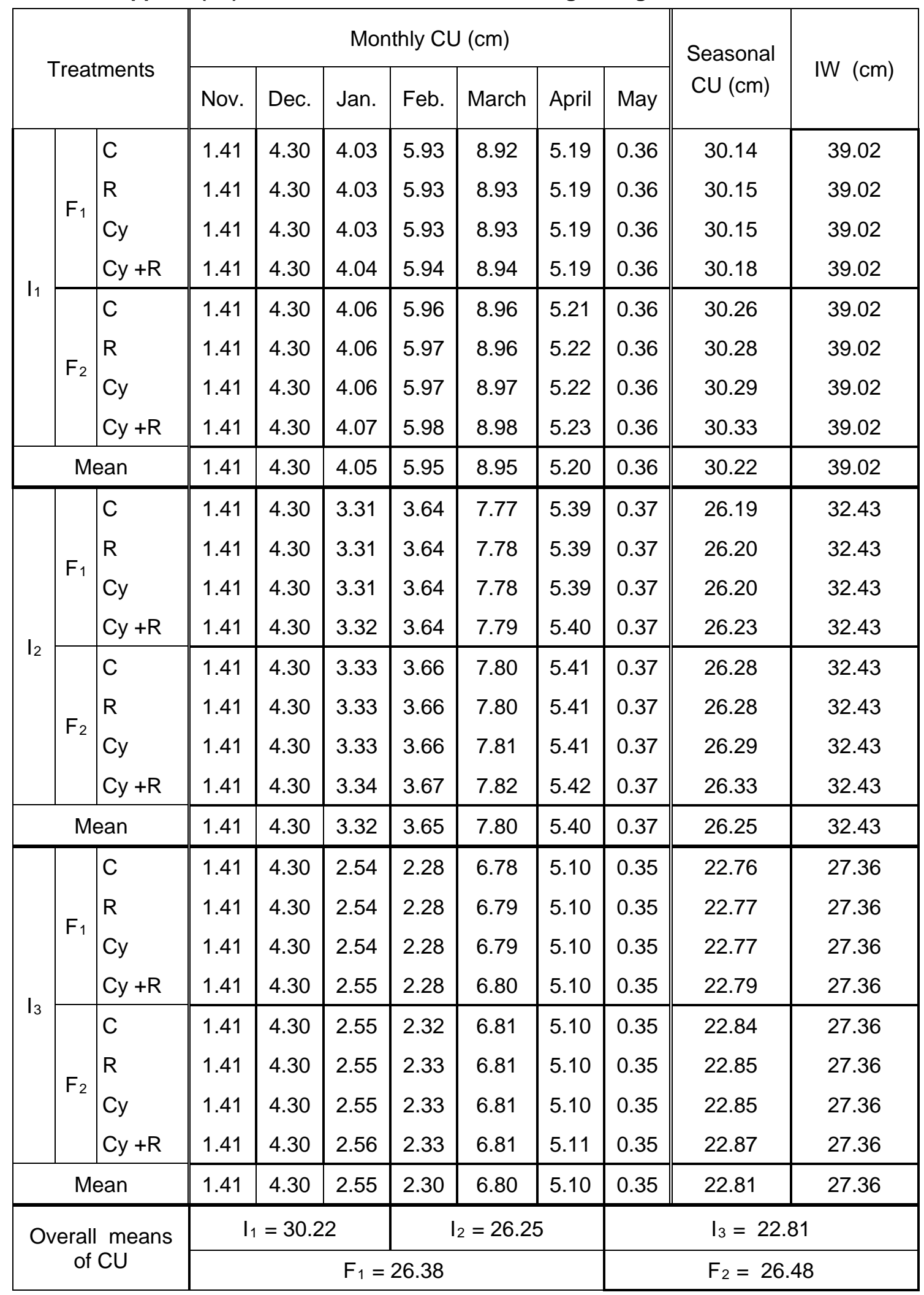




\section{Contribution of groundwater}

In the studied area, water table depth fluctuation ranged from $35 \mathrm{~cm}$ to $55 \mathrm{~cm}$ on all growing season. At late season, when irrigation stopped, groundwater, moved down up to a depth of $80-85 \mathrm{~cm}$ as mean of the two growing seasons. There are a slight difference in water table depth fluctuation between different irrigation treatments as a mean of the two growing season as shown in Fig (1). So the percentage of groundwater contribution to wheat water consumptive use in this experiment is very important especially when applying deficit irrigation such as $I_{3}$ irrigation treatment.

The percentage of groundwater contribution using $\mathrm{ET}_{\mathrm{c}}$ values obtained by the class A pan method is higher than that at Penman Montieth. Irrigation treatment of $I_{3}$ gave the highest percentage of groundwater contribution to be $50.4 \%$ and $41.6 \%$ using class A pan and Penman Montieth methods respectively, as a mean of the two growing seasons. Irrigation treatment of $I_{1}$ resulted in the lowest percentage of groundwater contribution to be $13.5 \%$ and $6.9 \%$ using class A pan and Penman Montieth methods respectively, this consider groundwater contribution to crop water use may be due to the contribution of shallow water table which increase capillary supplied and groundwater contribution to crop water use varied from $18 \%$ to $40 \%$ (Ayars et al., 2006; Babajimopoulos et al., 2007; Gowing et al., 2009; Huo et al., 2012; Karimov et al., 2014 and Soppe and Ayars, 2003). The mean percentage of groundwater contribution has the descending order $I_{3}>I_{2}>I_{1}$, it is about $46 \%, 26.9 \%$ and $10.2 \%$ for $I_{3}, I_{2}$ and $I_{1}$ respectively as a mean of the two growing seasons. This result agree with (Babajimopoulos et al., 2007 and Sepaskhah et al., 2003) who reported that under shallow water table, the interval between irrigation could be increase. The seasonally averaged ratio of the groundwater contribution to crop-water use varied with the seasonal water input and depth of water table, the ratio reached about $75 \%$ in case of water table depth about $1 \mathrm{~m}$ with no irrigation. This ratio decreased to $3 \%$ in case of water table depth more than $3.0 \mathrm{~m}$ and three irrigation applications as shown in Fig (2).

Data in Fig. (3) illustrate that the highest total seasonal water input was associated with $I_{1}$ which was $5000 \mathrm{~m}^{3} \mathrm{ha}^{-1}$ that divided to three components, $78 \%$ for irrigation, $15.8 \%$ for effective rain and $6.2 \%$ for groundwater contribution. While the lowest seasonal water applied was associated with $\mathrm{I}_{3}$ to be $4575 \mathrm{~m}^{3} \mathrm{ha}^{-1}$, which divided to $59.8 \%$ for irrigation, $17.3 \%$ for effective rain and $22.9 \%$ for groundwater contribution. The total seasonal water applied decreased by $5.2 \%$ and $8.5 \%$ with the irrigation treatments of $I_{2}$ and $I_{3}$ compared to $I_{1}$ respectively as mean of the two growing seasons. These result are harmony with those obtained by (Babajimopoulos et al., 2007; Gowing et al., 2009; Huo et al., 2012; Karimov et al., 2014; Kruse et al., 1986; Soppe and Ayars, 2003 and Yang et al., 2007) who mentioned that the significant contribution of groundwater to meet part of crop water requirement and should take it in consideration when scheduling irrigation, thus could reduce applied irrigation to achieve water saving.

\section{Productivity of irrigation water (PIW) and water productivity (WP)}

Data in Table (8) show that there are a significant difference in PIW and WP between irrigation treatments, nitrogen levels and PGPR treatments, the highest values of PIW and WP resulted from $F_{2}$ and $R+C y$ compared to $F_{1}$ and with other PGPR treatments as mean of the two growing seasons, this may be due to the higher grain yield compared to the other treatments. The highest values of PIW resulted from $I_{3}$ while the lowest values of PIW resulted from $I_{1}$. This results agree with (Bandyopadhyay and Mallick, 2003) who found that productivity of irrigation water increased when irrigation 
intervals increased. The highest values of WP were observed with $I_{1}$ and $I_{2}$ without any significant differences between them while the lowest values resulted from $I_{3}$. This may be due to the higher grain yield of $I_{1}$ and $I_{2}$ compared to $I_{3}$. As for the interaction among irrigation, $\mathrm{N}$-fertlizer and PGPR treatments, the highest values of PIW and WP were obtained under $\mathrm{I}_{2} \times \mathrm{F}_{2} \times \mathrm{R}+\mathrm{Cy}, \mathrm{I}_{3} \times \mathrm{F}_{2} \times$ $\mathrm{R}+\mathrm{Cy}$, and $\mathrm{I}_{3} \times \mathrm{F}_{1} \times \mathrm{R}+\mathrm{Cy}$ interactions without any significant differences between them, while the lowest values were obtained under $I_{3} \times F_{1} \times C$ as a mean of the two growing season. It could be due to that Rhizobium can increase the photosynthetic rate, transpiration velocity, stomatal conductance and flag leaf area of the plant therefore it is increasing water utilization efficiency (Chi et al., 2005) in addition to the role of cyanobacteria, which accumulated higher levels of indoleacetic acid and gibberellin phytohormones (Jaiswal et al., 2008). Plant-growth-promoting rhizobacteria was increased chlorophyll content, the root and shoot biomass, height of plants, yield and the wheat plants could withstand water stress more efficiently, enhanced antioxidant responses and increased accumulation of antioxidants such as carotenoids and ascorbate (Chakraborty et al., 2013).

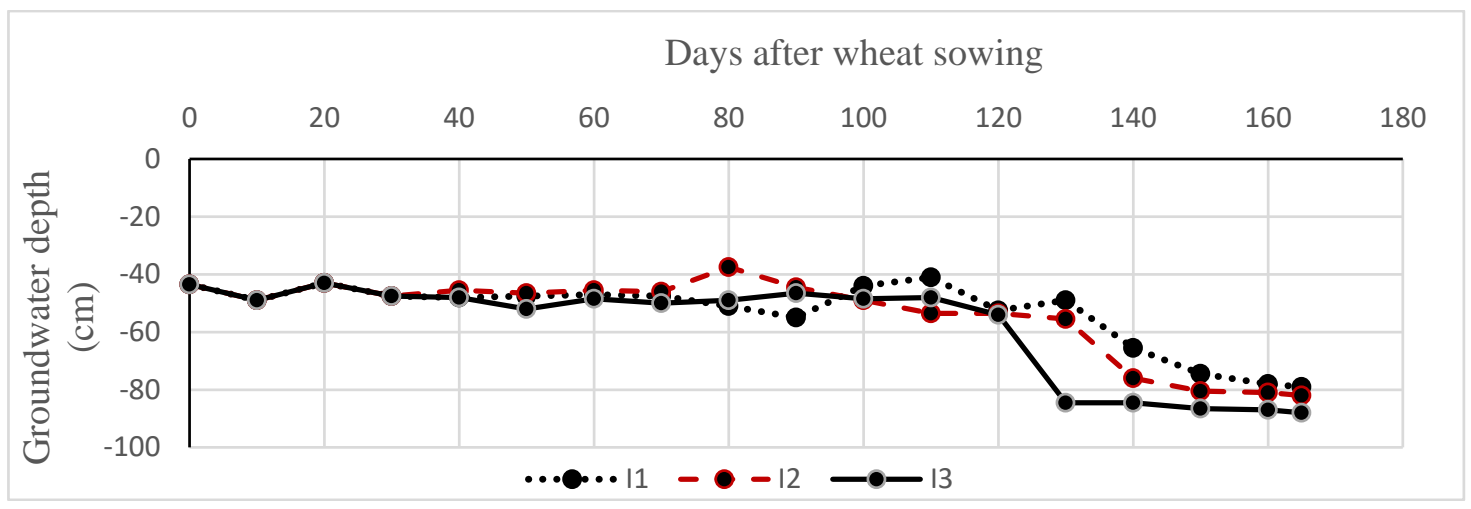

Fig (1): Fluctuation of groundwater table during growth period as a mean of the two growing season.

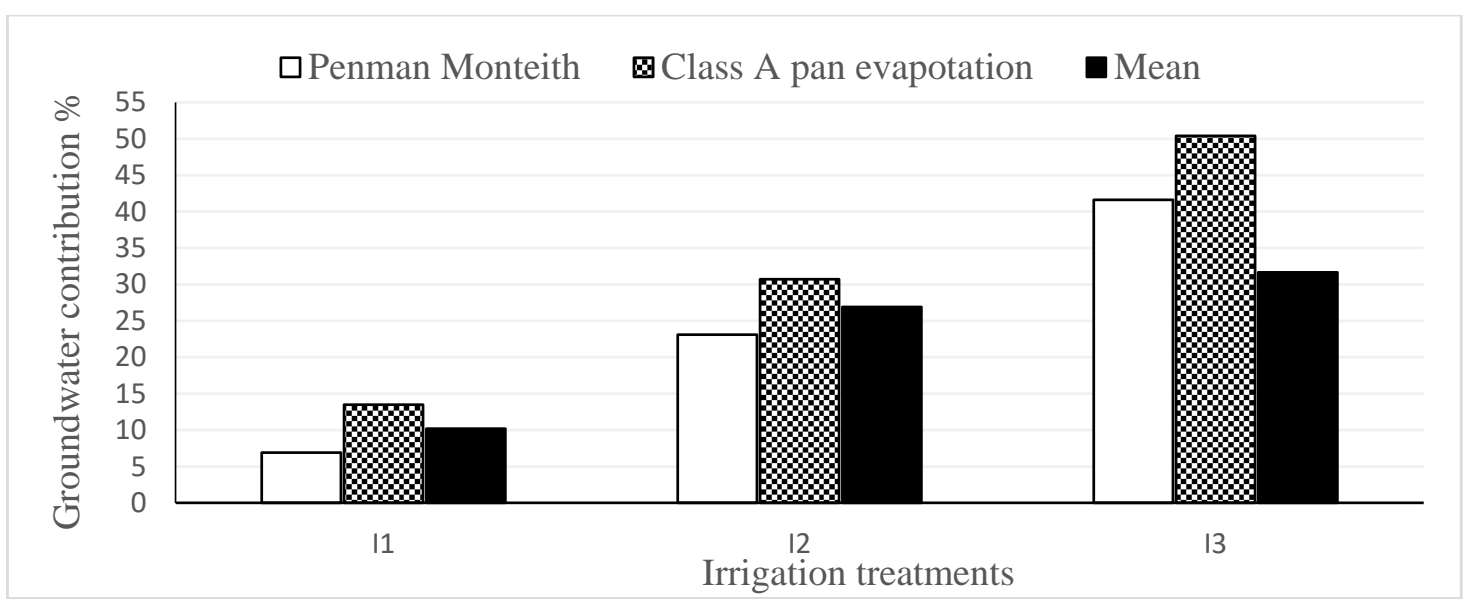

Fig (2): Groundwater contribution to wheat consumptive use using Penman Monteith and class A pan evaporation method as mean of the two growing seasons. 


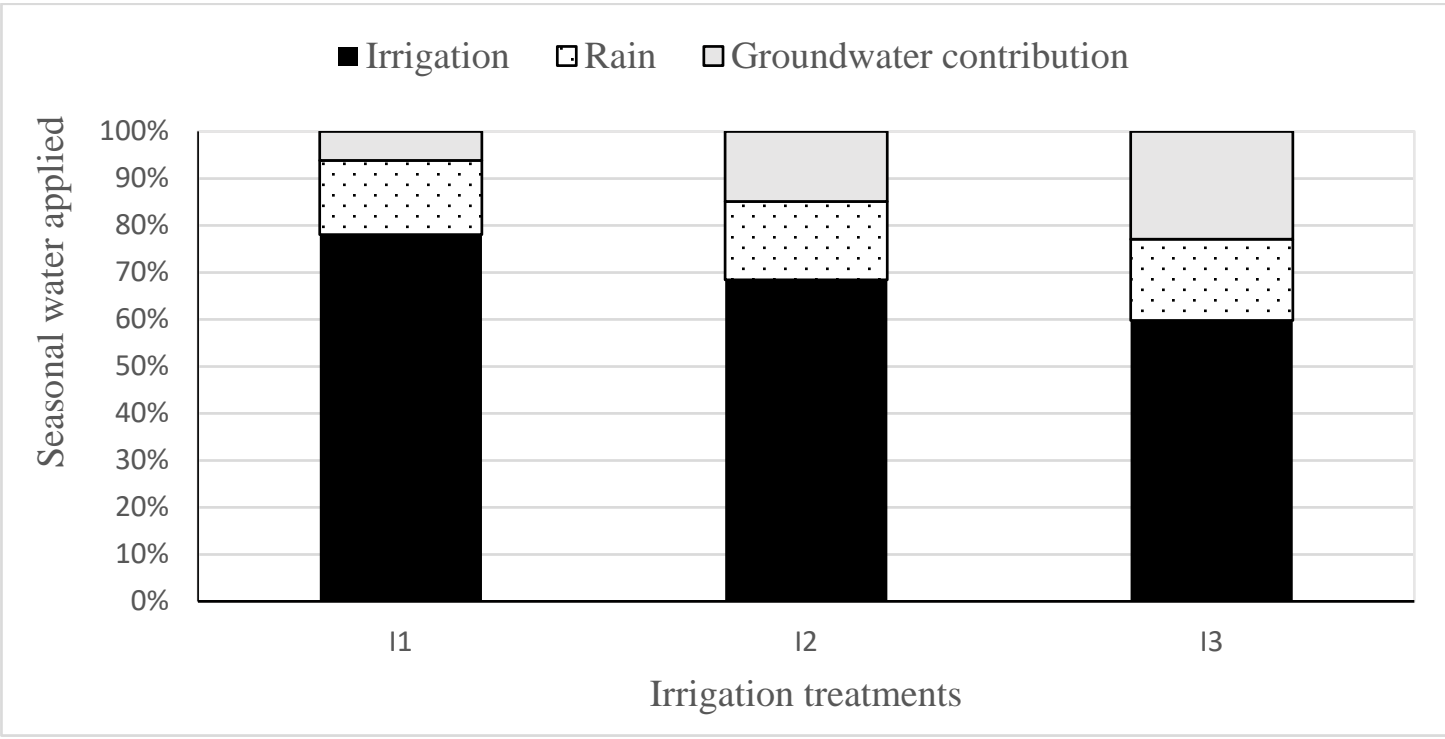

Fig (3): Average of total seasonal water applied over both seasons.

Table (8): Influence of irrigation scheduling, nitrogen levels and PGPR on productivity of irrigation water and water productivity of wheat over both seasons.

\begin{tabular}{|c|c|c|c|c|c|c|c|c|c|}
\hline \multirow{3}{*}{ Irrigation } & \multicolumn{8}{|c|}{ WP } & \multirow{3}{*}{$\begin{array}{c}\text { Over al } \\
\text { means }\end{array}$} \\
\hline & \multicolumn{4}{|c|}{$F_{1}$} & \multicolumn{4}{|c|}{$\mathrm{F}_{2}$} & \\
\hline & C & $\mathrm{R}$ & Cy & $\mathrm{R}+\mathrm{Cy}$ & C & $\mathrm{R}$ & Cy & $R+C y$ & \\
\hline$I_{1}$ & $1.23^{g h}$ & $1.58^{\text {cdef }}$ & 1.62 cde & $1.41^{\text {defg }}$ & $1.4^{\mathrm{efg}}$ & $1.63 \mathrm{bcd}$ & $2.07^{\mathrm{a}}$ & $1.96^{\mathrm{a}}$ & $1.61^{a b}$ \\
\hline $\mathrm{I}_{2}$ & $\begin{array}{c}1.23 \\
\mathrm{gh}\end{array}$ & $1.85^{a b}$ & $1.46^{\text {cdef }}$ & $1.95^{\mathrm{a}}$ & $1.42^{\text {defg }}$ & $1.55^{\text {cdef }}$ & $1.69^{b c}$ & $2.01^{a}$ & $1.65^{\mathrm{a}}$ \\
\hline$I_{3}$ & $1.05^{\mathrm{h}}$ & $1.36^{\mathrm{fg}}$ & 1.59 cde & $1.92^{\mathrm{a}}$ & 1.39 efg & 1.61 cde & $1.65^{\mathrm{bc}}$ & $1.96^{\mathrm{a}}$ & $1.57^{\mathrm{b}}$ \\
\hline \multirow{2}{*}{$\begin{array}{c}\text { Over all } \\
\text { means }\end{array}$} & \multicolumn{4}{|c|}{$\mathrm{F}_{1}=1.52^{\mathrm{b}}$} & \multicolumn{4}{|c|}{$\mathrm{F}_{2}=1.70^{\mathrm{a}}$} & \\
\hline & \multicolumn{2}{|c|}{$C=1.29^{c}$} & \multicolumn{2}{|c|}{$R=1.60^{b}$} & \multicolumn{2}{|c|}{ Cy $=1.68^{b}$} & \multicolumn{2}{|c|}{$\mathrm{R}+\mathrm{Cy}=1.87^{\mathrm{a}}$} & \\
\hline & \multicolumn{8}{|c|}{ PIW } & \\
\hline$I_{1}$ & $1.58^{k}$ & $2.02^{\mathrm{ij}}$ & $2.08^{\mathrm{hij}}$ & $1.81^{\mathrm{jk}}$ & $1.8^{\mathrm{jk}}$ & 2.09 hij & 2.65 bcdef & $2.52^{\text {cdefg }}$ & $2.07^{c}$ \\
\hline $\mathrm{I}_{2}$ & $1.81^{\mathrm{jk}}$ & $2.72 \mathrm{bcd}$ & 2.14 ghij & $2.85^{b c}$ & $2.08 \mathrm{hij}$ & $2.27^{\text {fghi }}$ & $2.47^{\text {cdefgh }}$ & $2.95^{\mathrm{ab}}$ & $2.41^{b}$ \\
\hline$I_{3}$ & $1.77^{\mathrm{jk}}$ & $2.28^{\text {efghi }}$ & $2.66^{\text {bcde }}$ & $3.22^{a}$ & $2.34^{\text {defghi }}$ & $2.70^{\mathrm{bcd}}$ & $2.77 \mathrm{bc}$ & $3.28^{a}$ & $2.63^{a}$ \\
\hline \multirow{2}{*}{$\begin{array}{l}\text { Over all } \\
\text { means }\end{array}$} & \multicolumn{4}{|c|}{$\mathrm{F}_{1}=2.45^{\mathrm{b}}$} & \multicolumn{4}{|c|}{$\mathrm{F}_{2}=2.49^{\mathrm{a}}$} & \\
\hline & \multicolumn{2}{|c|}{$C=1.9^{c}$} & \multicolumn{2}{|c|}{$R=2.38^{b}$} & \multicolumn{2}{|c|}{$\mathrm{Cy}=2.46^{\mathrm{b}}$} & \multicolumn{2}{|c|}{$R+C y=2.77^{a}$} & \\
\hline
\end{tabular}

Means designed by the same letter at each cell are not significantly different at the $5 \%$ Level according to Duncan's multiple range test 
Productivity of irrigation water and water productivity are good relation between irrigation water applied and grain yield because they increase when grain yield increase and/or water applied decrease (Ali et al., 2007; Ghane et al., 2009 and Zwart and Bastiaanssen, 2004).

\section{CONCLUSION}

In the studied area of North Nile Delta, Egypt where lack of irrigation water and shallow water table, farmers should add irrigation water at the time of actual need of the crop with just enough water to wet the effective root zone soil via applying irrigation scheduling at $90 \pm 5 \%$ with the addition of $75 \%$ of the recommended nitrogen fertilizer and inoculation with a consortium $\mathrm{N}_{2}$ - fixing cyanobacteria and Rhizobium (Cy+R) because it increased WP and PIW by $37 \%$ and $79 \%$ respectively, as well as saved nitrogen fertilizer and irrigation water by $25 \%$ and $30 \%$ respectively compared to $\mathrm{I}_{1}$ with $\mathrm{F}_{2}$ and $C$. As well as enhancing use of groundwater contribution under water scarcity areas.

\section{REFERENCES}

Adnan, M., Z. Shah, A. Khan, G.A. Khan, A. Ali, N.A. Khan, N. Saleem, S. Nawaz, S. Akbar and S. Samreen (2014). Integrated effects of rhizobial inoculum and inorganic fertilizers on wheat yield and yield components. Am. J. Plant Sci. 5: 2066-2073.

Afzal, A. and B. Asghari (2008). Rhizobium and phosphate solubilizing bacteria improve the yield and phosphorus uptake in wheat (Triticum aestivum). Int J Agric Biol 10: 85-88.

Agricultural Economics Research Institute, (2015). National agricultural income estimates (Ministry of Agriculture and Land Reclamation).

Ali, M.H., M.R. Hoque, A.A. Hassan and A. Khair (2007). Effects of deficit irrigation on yield, water productivity, and economic returns of wheat. Agric. Water Manag. 92: 151-161.
Allen, R.G.; L.S. Pereira; D. Raes and M. Smith (1998). Crop evapotranspirationGuidelines for computing crop water requirements. Irrig. Drain. Pap. 56 FAO, Rome 300, D05109.

Apte, S.K. (2001). Coping with salinity/water stress: cyanobacteria show the way. Proceedings-Indian Natl. Sci. Acad. part B 67: 285-309.

Ayars, J.E., E.W. Christen and J.W. Hornbuckle (2006). Controlled drainage for improved water management in arid regions irrigated agriculture. Agric. Water Manag. 86: 128-139.

Ayars, J.E., P. Shouse and S.M. Lesch (2009). In situ use of groundwater by alfalfa. Agric. Water Manag. 96: 15791586.

Babajimopoulos, C., A. Panoras, H. Georgoussis and G. Arampatzis (2007). Contribution to irrigation from shallow water table under field conditions. Agric. Water Manag. 92: 205-210.

Bandyopadhyay, P.K. and S. Mallick (2003). Actual evapotranspiration and crop coefficients of wheat ( Triticum aestivum ) under varying moisture levels of humid tropical canal command area. Agric. Water Manag. 59:33-47.

Black, C.A. (1965). Methods of Soil Analysis: 2 Parts. American Society of Agronomy.

Braun, H.J., G. Atlin and T. Payne (2010). Multi-location testing as a tool to identify plant response to global climate change. Clim. Chang. Crop Prod. 1: 115-138.

Chakraborty, U., B.N. Chakraborty, A.P. Chakraborty and P.L. Dey (2013). Water stress amelioration and plant growth promotion in wheat plants by osmotic stress tolerant bacteria. World $\mathrm{J}$. Microbiol. Biotechnol. 29:789-803.

Chi, F., S.H. Shen, H.P. Cheng, Y.X. Jing, Y.G. Yanni and F.B. Dazzo (2005). Ascending migration of endophytic rhizobia, from roots to leaves, inside rice plants and assessment of benefits to rice growth physiology. Appl. Environ. 
Microbiol. 71: 7271-7278.

Delfine, S., R. Tognetti, F. Loreto and A. Alvino (2002). Physiological and growth responses to water stress in field-grown bell pepper (Capsicum annuum L.). J. Hortic. Sci. Biotechnol. 77: 697-704.

Dimkpa, C., T. Weinand and F. Asch (2009). Plant-rhizobacteria interactions alleviate abiotic stress conditions. Plant Cell Env. 32:1682-1694.

Doorenbos, J., A.H. Kassam, C.L.M. Bentvelsen and V. Bronchied (1979). Yield response to water. Irrig. Drain. Pap. No. 33 Rome, Italy.

Doorenbos, J. and W.O. Pruitt (1977). Guidelines for predicting crop water requirements FAO. Irrig. Drainage, Pap. 24, FAO, Rome, Italy

Duncan, D.B. (1955). Multiple range and multiple $\mathrm{F}$ tests. Biometrics 11, 1-42.

El- Nawawy, A.S., M. Lotfi and M. Fahmy (1958). Studies on the ability of some blue- green algae to fix atmospheric nitrogen and their effect on growth and yield of paddy. Agric. Res. Rev., Min. Agric., Cairo 36: 308-320.

Eldardiry, E.I., M. Abd El-Hady and S.M. ElAshry (2010). Effect of water regime and Potassium application on water relations and nutrient uptake of wheat plant. Int. J. Acad. Res., 2: 75-82.

FAO, (2010). Food Outlook Report, http://www.fao.org/docrep/./ak349e00.pdf (accessed 20.01.11).

FAOSTAT, (2013). Production domain. In: Crops. FAO, Rome (accessed 20.12.13).

Giriappa, S. (1983). Water use Efficiency in Agriculture. Oxford \& IBH Publishing co. pvt. Itd.

Gowing, J.W., D.A. Rose and H. Ghamarnia (2009). The effect of salinity on water productivity of wheat under deficit irrigation above shallow groundwater. Agric. Water Manag. 96: 517-524.

Hammad, S.A.R. and O.A.M. Ali (2014). Physiological and biochemical studies on drought tolerance of wheat plants by application of amino acids and yeast extract. Ann. Agric. Sci. 59: 133-145.
Hilali, A., D. Prevost, W.J. Broughton and $\mathrm{H}$. Antoun (2001). Effects of inoculation with Rhizobium leguminosarum biovar trifolii on wheat cultivated in clover crop rotation agricultural soil in Morocco. Can. J. Microbiol. 47:590-593.

Huo, Z., S. Feng, G. Huang, Y. Zheng, Y. Wang and P. Guo (2012). Effect of groundwater level depth and irrigation amount on water fluxes at the groundwater table and water use of wheat. Irrig. Drain. 61: 348-356.

Hussain, M.B., Z.A. Zahir, H.N. Asghar and M. Asghar (2014). Can catalase and exopolysaccharides producing rhizobia ameliorate drought stress in wheat. Int $\mathrm{J}$. Agric. Biol. 16:3-13.

Israelsen, O.W. and V.E. Hansen (1962). Irrigation Principles and Practices 3rd Edit. John Willey and Sons. Inc., New York.

Jaiswal, P., R. Prasanna, S. Nayak, A. Sood and M.R. Suseela (2008). Characterization of rhizo-cyanobacteria and their associations with wheat seedlings. Egypt J. Biol., 10: 20-27.

Jalali, V., S. Asadi and M. Homaee (2017). Evaluating performance of macroscopic water uptake models at productive growth stages of durum wheat under saline conditions. Agric. Water Manag. 180: $13-21$.

James, L.G. (1988). Principles of Farm Irrigation System Design. John Willey\&Sons (ed.), New Yourk, pp.543.

Kahlown, M.A. and M. Ashraf (2005). Effect of shallow groundwater table on crop water requirements and crop yields. Agric. Water Manag. 76: 24-35.

Kang, S., L. Zhang, Y. Liang and X. Hu (2002). Effects of limited irrigation on yield and water use efficiency of winter wheat in the Loess Plateau of China. Agri Cult. Water Manag. 55: 203-216.

Karimov, K.A., J. Sim, M.A. Hanjra, M. Avliyakulov and I. Forkutsa (2014). Effects of the shallow water table on water use of winter wheat and ecosystem health: Implications for unlocking the 
potential of groundwater in the Fergana Valley ( Central Asia ). Agric. Water Manag. 131: 57-69.

Karrou, M., T. Oweis, R. Abou, E. Enein and M. Sherif (2012). Yield and water productivity of maize and wheat under deficit and raised bed irrigation practices in Egypt. African J. Agric. Res. 7:17551760.

Khan, M.J., T. Sarwar, A. Shahzadi and A. Malik (2007). Effect of different irrigation schedules on water use and yield of wheat. Sarhad J. Agric. 23: 1061-1066.

Klute, A. (1986). Methods of Soil Analysis, part 1: Physical and Miner-alogical Methods (2nd) Ed Ameri-can Soci. of Agronomy, Madison, Wisconsin, USA.

Kruse, E.G., R.E. Yoder, D.L. Cuevas and D.F. Champion (1986). Alfalfa water use from high, saline water tables. Am. Soc. Agric. Eng. Microfich. Collect.

Li, S.-X., Z.H. Wang, S.S. Malhi, S.Q. Li, Y.J. Gao and X.H. Tian (2009). Nutrient and water management effects on crop production, and nutrient and water use efficiency in dryland areas of China. Adv. Agron. 102: 223-265.

Luo, Y. and M. Sophocleous (2010). Seasonal groundwater contribution to crop-water use assessed with lysimeter observations and model simulations. J. Hydrol. 389: 325-335.

Mussa, S.A., M.H. Mona and F.M. Ghaza (2003). Effect of cyanobacteria-wheat association on wheat growth and yield components. Egypt. J. Biotechnol. 14: 164-174.

Nain, L., A. Rana, M. Joshi, S.D. Jadhav, D. Kumar, Y.S. Shivay, S. Paul and R. Prasanna (2010). Evaluation of synergistic effects of bacterial and cyanobacterial strains as biofertilizers for wheat. Plant Soil, 331:217-230.

Nakkeeran, S., W.G.D. Fernando and Z.A. Siddiqui (2005). Plant growth promoting rhizobacteria formulations and its scope in commercialization for the management of pests and diseases, in: Biocontrol and Biofertilization. Springer, pp. 257-296.
Namich, A.A.M. (2007). Response of cotton cultivar Giza 80 to application of glycine betaine under drought conditions. Minufiya J. Agric. Res. 32: 1637-1651.

Nouri, M., M. Homaee, M. Bannayan and G. Hoogenboom (2016). Towards modeling soil texture-specific sensitivity of wheat yield and water balance to climatic changes. Agric. Water Manag. 177: 248263.

Novica, V. (1979). Irrigation of agriculture crops. Fac. Agric. Press, Novi Sad, Yugoslavia.

Nwachukwu, O.I. and M.C. Ikeadigh (2012). Water use efficiency and nutrient uptake of maize as affected by organic and inorganic fertilizer. PAT 8:199-208.

Osborne, S.L., J.S. Schepers, D.D. Francis and M.R. Schlemmer (2002). Use of spectral radiance to estimate in season biomass and grain yield in nitrogen and water stressed corn. Crop Sci. 42: 165171.

Page, A.L., R.H. Miller and D.R. Keeney (1982). Methods of Soil Analysis Chemical and Microbiological Properties. Madison, Wisconsin.

Pandey, R.K., J.W. Maranville and A. Admou (2001). Tropical wheat response to irrigation and nitrogen in a Sahelian environment. I. Grain yield, yield components and water use efficiency. Eur. J. Agron. 15: 93-105.

Paredes, P., G.C. Rodrigues, M. R. Cameira, M.O. Torres and L.S. Pereira (2017). Assessing yield, water productivity and farm economic returns of maltbarley as influenced by the sowing dates and supplemental irrigation. Agric. water manag. 179:132-143.

Pradhan, S., U.K. Chopra, K.K. Bandyopadhayay, R. Singh, A.K. Jain and I. Chand (2014). Effect of deficit irrigation and nitrogen levels on water productivity and nitrogen use efficiency of wheat (Triticum aestivum) in a semi-arid environment. Indian J. Agric. Sci. 84(7):887-891.

Prasanna, R., P. Jaiswal, J. Shrikrishna, M. 
Joshi, L. Nain, A. Rana and Y.S. Shivay (2012). Evaluating the potential of rhizocyanobacteria as inoculants forrice and wheat. J. Agric. Technol. 8: 157-171.

Rizk, A.H. and M.M. Sherif (2014). Effect of soil moisture depletion on the yield of wheat under sprinkler irrigation at Toshka area, Egypt. Middle East J. Agric. Res. 3: 981-987.

Safa, M. and S. Samarasinghe (2011). Determination and modelling of energy consumption in wheat production using neural networks:A case study in Canterbury province, New Zealand. Energy 36: 5140-5147.

Sepaskhah, A.R., A. Kanooni and M.M. Ghasemi (2003). Estimating water table contributions to corn and sorghum water use. Agric. Water Manag. 58: 67-79.

Smith, M. (1992). CROPWAT: A computer program for irrigation planning and management", FAO. Irrig. Drain. Pap. No. 46, Rome, Italy.

Soppe, R.W.O. and J.E. Ayars (2003). Characterizing ground water use by safflower using weighing lysimeters. Agric. water Manag. 60: 59-71.

Vincent, J.M. (1970). A manual for the practical study of the root-nodule bacteria. A Man. Pract. study root-nodule Bact.
Vomocil, J.A. (1957). Measurement of soil bulk density and penetrability: A review of methods. Adv. Agron. 9: 159-175.

Yang, J., J.W. Kloepper and C. Ryu (2009). Rhizosphere bacteria help plants tolerate abiotic stress. Trends Plant Sci 14: 1-4.

Yang, J., S. Wan, W. Deng and G. Zhang (2007). Water fluxes at a fluctuating water table and groundwater contributions to wheat water use in the lower Yellow River flood plain, China. Hydrol. Process. 724: 717-724.

Yanni, Y.G., F.B. Dazzo, A. Squartini, M. Zanardo, M.L. Zidan and A.E.Y. Elsadany (2016). Assessment of the natural endophytic association between Rhizobium and wheat and its ability to increase wheat production in the Nile delta. Plant Soil 407: 367-383.

Zhu, Y., Z. Wang, J. Wang, Z. Wang and J. Zhou (2014). Plant growth-promoting rhizobacteria improve shoot morphology and photosynthesis in dryland spring wheat. . WIT Trans. Built Environ. 145: 343-350.

Zwart, S.J. and W.G.M. Bastiaanssen (2004). Review of measured crop water productivity values for irrigated wheat, rice, cotton and maize. Agric. water Manag. 69: 115-133.

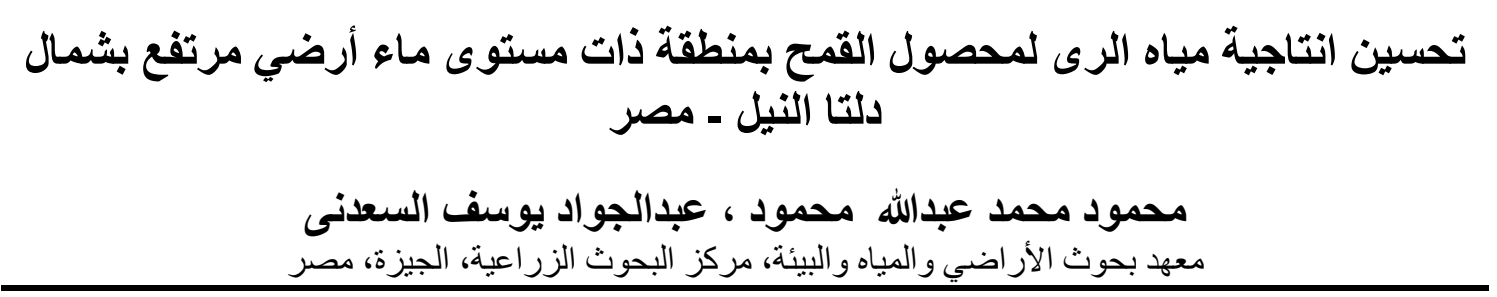


الملخص العربى الجربى

اجريت تجربتان حقليتان بمحطة البحوث الزراعية بسخاـ شمال دلتا النيل خلال الموسمين الزراعيين 2014 /2015 و

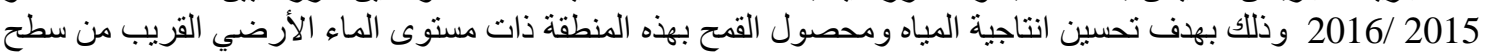

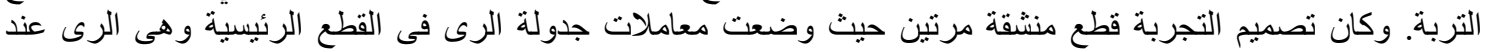

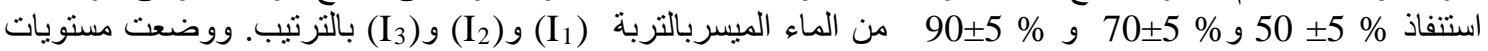

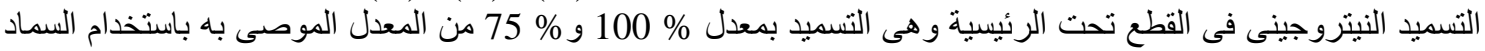

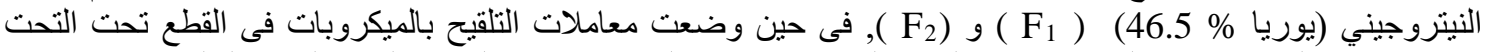

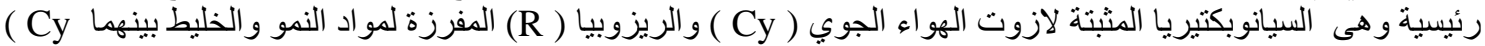

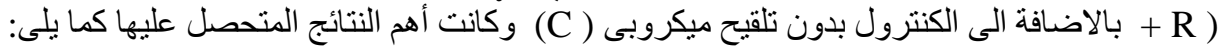

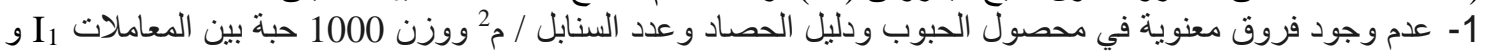

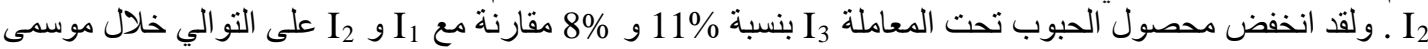
الز الزراعة.

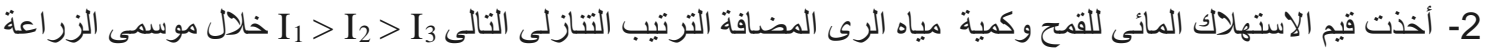

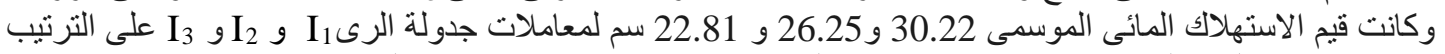

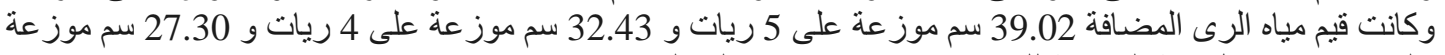

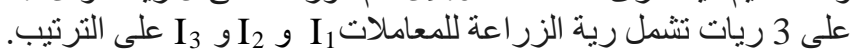

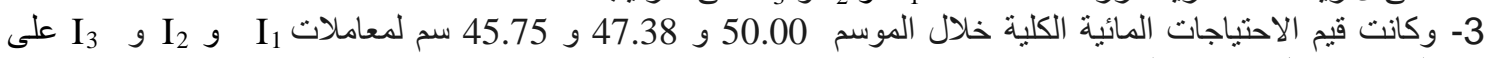

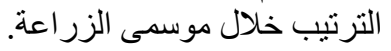

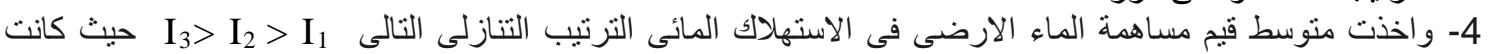

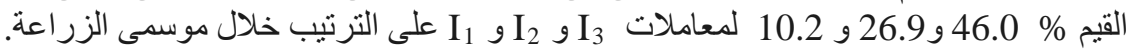

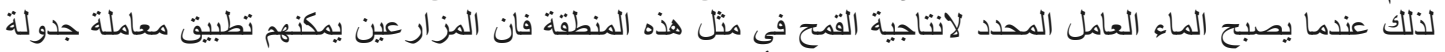

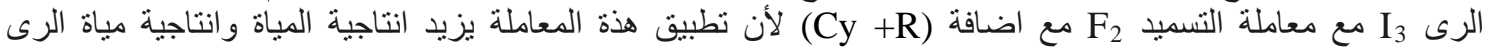

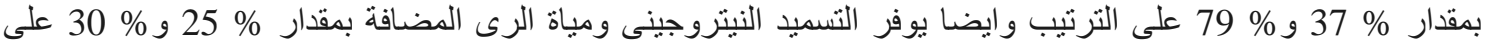

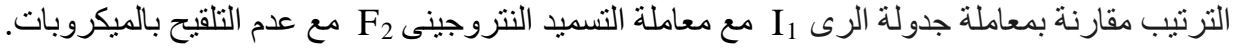

